\title{
'Defensive Liberal Wars': The Global War on Terror and the Return of Illiberalism in American Foreign Policy
}

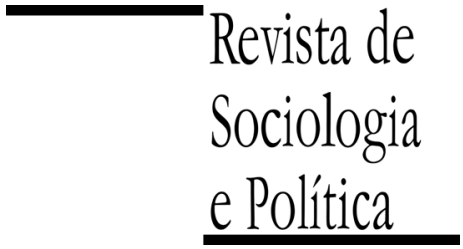

DOI 10.1590/1678-987315235306

\author{
Rashmi Singh
}

\begin{abstract}
This paper offers an analysis of the illiberal practices and discourse of the Global War on Terror (GWoT) and demonstrates how the United States of America used the liberal argument as a qualitative metric of its success and failure in the GWoT. I argue that 'the othering' of Salafi Jihadists as well the full military involvement in Afghanistan and Iraq were both philosophically rooted in the liberal thinking of Immanuel Kant and John Stuart Mill, which have traditionally guided US foreign policy. More significantly, these liberal philosophies of history and international relations hold within them the seeds of illiberalism by depicting non-liberal, undemocratic societies/organisations as 'barbaric' - and as such prime candidates for intervention and regime change. Predicated upon this logic, the discourse of the GWoT framed Al Qaeda as a key existential threat to not only the United States but also the 'civilised world' in general and one which required a 'liberal defensive war' in response. It was the successful securitisation of Al Qaeda that essentially enabled the United States to adopt deeply illiberal policies to counter this so-called existential threat by using any means at its disposal.
\end{abstract}

KEYWORDS: Liberalism; Global War on Terror; United States; Immanuel Kant; John Stuart Mill.

Recebido em 13 de Agosto de 2014. Aprovado em 18 de Outubro de 2014.

\section{Introduction ${ }^{1}$}

When George W. Bush addressed a joint session of Congress and the American nation in the aftermath of the September 11 attacks, perhaps no one could have predicted that the following decade would see the scale of intervention that followed in Afghanistan and Iraq, with concomitantly high levels of not only civilian deaths but also the unintended security fallouts that are more than evident in the Middle East today. More significantly, perhaps no one could have predicted the deeply illiberal policies and practices that would be adopted by the United States (US) in order to address the threat of Al Qaeda and its allies. These practices seen, amongst others, in cases such as the Abu Ghraib scandal, the Guantanamo Bay prison camp, the use of targeted assassinations and extraordinary renditions, not only bring into question the very essence of liberal values that the United States purports to uphold but also engender a deeper questioning of the relevance of liberalism in today's world.

In this article, I undertake an analysis of the neoconservative discourse and practice of the Global War on Terror (GWoT) as evidenced through statements made by George W. Bush and other key members of his administration. This analysis demonstrates how the United States of America, under the Bush administrations, has used what is in essence a liberal argument as a qualitative metric of its success and failure in the GWoT. I argue that the foundation for 'the othering' of Salafi Jihadists as well as the identification of specific geographical locales for full military intervention (Afghanistan and Iraq) are both based in the liberal states' construction of an argument that depicts these societies/agents/organisations as undemocratic, barbaric, backward and illiberal - in 
${ }^{2}$ This view is by no means unique and, as will be made clear over the course of this paper, several established political scientists and International Relations theorists have argued both for and against this position.

There is also a robust debate on whether or not Immanuel Kant can be categorised as a liberal philosopher, although in this paper I have deliberately chosen to view him as a liberal thinker. other words, as prime candidates for armed intervention and regime change. Predicated upon this logic, the administrations of President George W. Bush, successfully framed Salafi-Jihadism as a key existential threat to not only the United States but also the 'civilised' liberal world order. Having successfully securitised the Al Qaeda brand of Salafi-Jihadism, the United States under the Bush administrations then framed itself as the guardian and upholder of democratic values seeking to preserve a liberal way of life in the face of what was an unprecedented threat. However, somewhat paradoxically, this was achieved through the adoption of deeply illiberal practices that have encouraged some to question the very foundations of both the American nation and the liberal world order.

In this article I argue that these deeply illiberal practices and policies can trace their roots to a long-standing tradition of liberalism and more particularly to the thinking of philosophers like Immanuel Kant and John Stuart Mill. To this end, I first outline the basis tenets of liberalism and liberal internationalism as used in this paper before outlining how the seeds of illiberalism can be located in the historical writings of Kant and $\mathrm{Mill}^{2}$. Having provided this context, I then identify how US foreign policy, at the very least from the $20^{\text {th }}$ century onwards, has not only championed intervention for democracy promotion but also how it has framed such intervention as a key national security imperative. This background will serve to contextualise the GWoT and highlight how it does not necessarily represent a sharp break from the policies adopted by previous US administrations - although it does admittedly signify a shift from the more benign liberalism of the 1990s. Once this theoretical and historical foundation has been laid, I will proceed to illustrate how the United States under the Bush administration deliberately securitised Al Qaeda by framing 9/11 as an exceptional act and used it to justify the interventions in Afghanistan and Iraq. The deliberate construction of this discourse will be then be illustrated through a thematic analysis of key communications from the Bush administrations, most particularly the Presidential State of Union addresses and US National Security Strategies.

\section{Tracing the illiberal roots of Liberalism}

The liberal euphoria that surfaced in the Western world in the early 1990s following the defeat of Soviet communist ideology has in recent times given way to exaggerated claims of a decline and defeat of the liberal international order in the early twentieth century. Much of this disillusionment can be credited to the recent global financial crisis, the rise of non-liberal powers and illiberal ideologies as well as the GWoT as it has unfolded since the horrific attacks of 11 September 2001. While the 9/11 attacks mobilised the United States into commencing a global fight against terrorism they also marked the adoption of deeply illiberal policies by a country that had been known for its long-standing liberal tradition. Over the past fourteen years these policies have not only engendered one of the most serious civil liberties crises within the United States but brought into question its commitment to the basic liberal values of individual rights at the international level as well.

Various scholars have suggested, either implicitly or explicitly, that the seeds of US illiberalism lie in its deep-rooted liberal tradition and that the neo-conservatives share more than a passing resemblance with so-called liberal 'purists' ${ }^{3}$ However, before I probe this link and given the 'varieties of liberalism' (Doyle 1997), it is useful to begin by stating exactly what liberalism means in the context of this article. Liberalism refers to a political system or a set of political values based on the legal equality of citizens, political representativeness, individual freedom and laissezfaire. In essence, it is grounded in the belief that

${ }^{3}$ See for example, Freedman (2005) and Williams (2006). 
${ }^{4}$ It is worth noting that Kant does not speak of 'democracy' but instead advocates a republican peace.

${ }^{5}$ While Desch's logic is used here to illustrate how contemporary US policy can trace its roots to liberal thinkers like Kant, this is not done to discredit liberalism. Desch, an unflinching realist, constructs this argument to illustrate liberalism's failures and to argue that realism should be used to check "liberal excesses". This paper however, uses this argument to illustrate the securitisation attempt that was initiated post-9/11 with the intention of defending the liberal values that the US stands for.

${ }^{6}$ This position is taken by both liberals as well as scholars from different schools of thought - though the latter tend to use it to bolster arguments to explain the insufficiencies of liberalism while the former use it to highlight the both the existence of many varieties of liberalism as well as some of the inherent contradictions that liberals must contend with.

${ }^{7}$ See also Brown (1992), Gallie (1978), and Kant (1983).

\footnotetext{
${ }^{8}$ Kant's idea of a pacific
}

the promotion of freedom is inextricably linked to peace in that governments that respect individual liberty are more likely to exercise restraint and have peaceful intentions in their foreign policies (idem). Founded on this logic, liberal internationalism has created a structure of international cooperation based on shared norms which have come to include a respect for human rights, non-intervention, anti-imperialism, free markets, political and religious tolerance as well a toleration of differing ideas as to what constitutes a good life (Grey 2004; Williams 2006). However, this definition belies the heavy-handed US response to the 9/11 attacks and its wars in Afghanistan and Iraq. Nonetheless, while this understanding of liberalism seemingly cannot explain the excesses that have characterised US foreign policy in the recent past, a closer look at Immanuel Kant's ideas in his influential essay Perpetual Peace (1797) certainly sheds some light upon how deeply illiberal policies may be adopted by a liberal state.

Michael Desch argues that Kant's 'Perpetual Peace' has exerted the greatest influence on U.S. foreign policy primarily through the theory of 'democratic peace' and it is in his work that the very roots of 'liberalism's illiberalism' can be located (Desch 2007) ${ }^{4}$. Those who adhere to this argument predicate it on the logic that Kant's thesis has provided the "philosophical rationale for efforts to promote peace through the spread of democracy under the auspices of international institutions such as Woodrow Wilson's League of Nations" (idem, p. 12$)^{5}$. It is certainly true that over the past century or so, liberal internationalism has come to encompass both a Wilsonian-like belief in the liberal state's moral duty to establish peace and liberty through the active spread of democracy as well as (in some circles) a belief that it is, in fact, in the liberal state's strategic interest to do so. It has, therefore, been argued ${ }^{6}$ that liberal states have overcome their distaste for external armed interventions in pursuit of this moral duty and in doing so have extended liberal values to peoples and places where they did not previously exist.

The philosophical roots of this argument may be traced to Kant's objective of establishing perpetual peace without the need for an overarching world government that was embodied in the first of his definitive articles, which states that: "nations should be republics and the constitution will be based on the civil rights of individuals within that state" (Williams 2006, p. 25)7. But for such a system to be effective it was imperative that all countries have the same republican domestic political order. Kant's reasoning is grounded in the belief that political systems where individuals, who more often than not tend to be directly impacted by the cost of wars, also have a say in whether it is waged are less likely to engage in this harmful activity (Desch 2007, p. 12). Hence, as Kant argues in the first definitive article, republics where citizens' opinions are reflected tend to be less inclined to engage in wars (Doyle 1996). In short, a perpetual peace can only be guaranteed only if all parties to it are liberal, 'democratic' states because only then will there be conditions established to not only facilitate a cessation of all hostilities but "an end to all hostilities" and therefore the end "of all existing reasons for future war"(my emphasis) (George 2000). Desch therefore points out that, unlike earlier social contract theorists like Thomas Hobbes and John Locke, Kant saw the state of nature as so treacherous that its dangers could only be mitigated by a radical transformation of both a country's internal domestic order as well as the international system. But more crucially for the purpose of this thesis, Kant conferred republican states with the right to bring to an end to the international state of war through the use of force against other states in order to compel them to embrace republicanism. He thus explains how, "for the sake of its own security, each nation can and should demand that others nations enter into a contract resembling the civil one and guaranteeing the rights of each" (Kant 1983, p. 116). In other words, the pacific union of liberal states" (Desch 2007, p. 13; Doyle 1986, p. 1160) ${ }^{8}$, which engen- 
union or federation (foedus pacificum) is described in his second definitive article and refers to a 'federation of free states', i.e. liberal republics which come together in "an enduring and gradually expanding federation likely to prevent war" (Doyle 1986).

See also Williams (2006,

p. 25).

${ }^{9}$ It may be noted that this is a specific reading of Kant's work and Desch concedes that other scholars, such as Michael Doyle and Kenneth N. Waltz, categorise him as a non-interventionist liberal. Nonetheless, Desch also points out that Doyle concedes to the "presence of ambiguities in Kant's liberalism" (Desch 2007). This ambiguity is especially notable with regards to Kant's categorisation of 'liberal wars', i.e. wars fought for freedom, the protection of private property and to aid liberal allies against non-liberal foes, as unjust. See Doyle (1983b; 1986). See also Waltz (1954)

${ }^{10}$ For a robust argument contradicting this view see Jahn (2005b) ders a society of states where the civil constitution of every nation is republican and thus guarantees the rights of each nation in the international system. Thus, Kant, arguably the greatest of the liberal internationalist, makes a fairly watertight case for the use of illiberal means including force, coercion and intervention to bring about change in the international system and in doing so marks a fundamental departure from classical international law with its unqualified commitment to state sovereignty ${ }^{9}$.

Desch goes on to clarify that while Kant's advocacy of forcible conversion to republicanism seems to contradict his fifth preliminary article which categorically forbids intervention in the domestic politics of other countries this is, in fact, not the case. This is because for liberals, "state sovereignty ultimately derives from the rights of individuals in the state of nature. When individuals surrender their natural liberty to the commonwealth through the social contract, then it inheres in the state" (Desch 2007, pp. 13-14). While intervention in the domestic affairs of such a representative states violates the individual rights of its citizens, a state which is not representative does not enjoy the same rights of non-intervention ${ }^{10}$. This is framed in Kant's idea of the 'unjust enemy' that he conceptualises in Metaphysics of Morals (1798), and which is defined as "one whose publicly expressed Will, either in word or deed, betrays a maxim which, if it were taken as a universal rule, would make a state of peace among the nations impossible, and would necessarily perpetuate the state of nature" (Jahn 2005 b, p. 14). An unjust enemy is one that refuses to adopt republicanism and in doing so threatens the pacific federation. In other words, non-republican states threaten the historical evolution towards the "end-state of a law ruled international society [and] as a consequence, not only the international community of states but each state is entitled to apply 'all means' [...] against this dangerous opponent" (Müller 2014, p. 479). This is how war remains a legitimate "instrument of statecraft in relation to authoritarian regimes" (Dunne 2009, p. 108).

A final key point that needs be made is how Kant's thesis allows a republican hegemon to actively promote the establishment of the republican league by inspiring other states to adopt a republican political order both domestically and in the international system (Doyle 1996; Desch 2007). Kant, therefore, promotes the idea that a gradual expansion of the foedus pacificum is necessary for the establishment of perpetual peace. Proponents of the democratic peace have seen this Kantian logic as the philosophical justification for active democracy promotion in the international system. Beate Jahn argues that while the issue of consent is never really discussed by democratic peace theorists, it is a central concern for not only liberal thought in general but also the democratic peace thesis in particular. Given that liberal institutions derive their legitimacy from consent, presumably the absence of consent denies non-liberal states of this very legitimacy. Logically, Jahn argues, this implies that citizens of non-liberal states would consent to liberal institutions, and yet they do not. This is possibly the result of various external and internal barriers, that may range from "political repression, or non-liberal cultural traditions [...] [to] simply a lack of exposure to the benefits of liberal life" (Jahn 2005b, p. 182). However, proponents of the democratic peace thesis, by founding themselves on logic of an expanding foedus pacificum, tend towards "interventionism irrespective of consent" (ibidem). In short, despite the presence of key tensions, by viewing the existence of non-liberal states as a threat to perpetual peace and the sustainable longevity of the pacific union, Kantian liberalism potentially provides the philosophical justification for the use of illiberal means of intervention, hegemony, coercive regime change and democracy promotion, thus illuminating the deeply illiberal roots of liberalism ${ }^{11}$. 


\section{Mill and the Logic of the Barbarian Other}

${ }^{11}$ This is admittedly a normative interpretation of Kant's Republican Peace. However, it is worth stating that there is a body of work that challenges this view by positing the predictive, rather than the normative nature of Kant's work. See (Huntley 1996; MacMillan 1996; Thompson 1996) - three works that resulted in a 'systemic' research programme on the Democratic Peace in the 2000s. I would like to thank my anonymous reviewer for bringing this critical point to my attention.

${ }^{12}$ It is worth noting here, that I argue that it is precisely within this tension, which authors like Jennifer Pitts and Beate Jahn identify as existing between liberalism's commitment to human dignity and equality on the one hand and the support that so many historical liberal thinkers professed for imperial conquest and governance on the other, that we can locate to borrow Desch's phrase 'liberalism's illiberalism'.

${ }^{13}$ Several authors, in addition to Pitts, claim that Mill's liberalism is intertwined with ideas of colonialism and imperialism. Among others, see for instance Jahn (2005a), Mehta (1999), Passavant (2002), and Souffrant (2000).

${ }^{14}$ Mill's ideal case is, of course, British culture and political organisation.

15 See also Mehta (1999).
If Kantian liberalism provides the philosophical grounding for intervention then John Stuart Mill's liberalism provides even further justification for spreading liberal values to 'barbarian' societies, which lack them in order to bolster the liberal project by expanding the pacific federation. Mill's theory, in stark contrast to early liberal philosophers like Adam Smith, Edmund Burke and Jeremy Bentham, is in essence a defence of colonial imperialism and a "civilising despotism' (Pitts 2005). Jennifer Pitts calls this the "liberal turn to empire" and argues that it was "accompanied by the eclipse of nuanced and pluralist theories of progress as they gave way to more contemptuous notions of 'backwardness' and a cruder dichotomy between barbarity and civilisation" (idem, pp. 2-3). Indeed it is in this dichotomy that J. S. Mill's philosophy of history most closely resembles contemporary liberal thought and fully reconciles the colonial imperial project with what are the core tenants of contemporary liberalism - in what Beate Jahn calls a "perfect match' ${ }^{12}$. Thus, Mill deploys the language of civilisation, savagery and barbarism to outline his view of the world and the stages in the development of history and to essentially justify imperialism and the colonial enterprise ${ }^{13}$. From these stages of history, he identifies modern civilisation as the highest form and claims that it embodies what were (by this time) the familiar liberal characteristics of "commerce, manufacture, agriculture, cooperation, social intercourse, law, justice, the protection of both individuals and property and in ideal cases, the existence of a representative government" (Jahn 2005b, p. 194) ${ }^{14}$.

Mill frames civilisation as the direct opposite of barbarism - indeed as Jahn so fittingly states, as the very "negation of barbarism" (Jahn 2005a). Framed in this manner, barbarians are a threat, the proverbial 'other' and everything that modern civilisation is not: infantile, incapable of 'self-government' (Pitts 2005, p. 5). violent and irrational. Mill's thought therefore makes an inherent distinction between a culturally superior and a culturally inferior peoples (idem, $\mathrm{p}$. 605), on the basis of which he argues that one set of rules must exist for relations between civilised nations and an entirely other set for those between civilised and barbarian nations. "[N]one but civilised nations have ever been capable of forming an alliance (Mill 1990, p. 49) because alliances require reciprocity, which barbarians are incapable of. As such, "they [i.e. barbarian nations] cannot be depended on for observing any rules" (Mill 1984, p. 118). Mill therefore constructs the relationship between civilised nations as necessarily governed by laws of equality where aggressive wars and intervention is non-existent and unnecessary. However, these ideas of equality and relations based in liberal principles only applied amongst civilised nations ${ }^{15}$. In sharp contrast, relations between civilised nations and barbarian people are necessarily hierarchical.

For Mill progress is critical and his focus remains unrelentingly upon "man as a progressive being" (Mill 2005, p. 14). His construction of different stages of history as a development from savagery to civilisation reflects both this philosophy and focus. However, Mill warns, progress from one stage to the next is by no means automatic. Indeed backward development and stagnation are real dangers and unfortunately "among the most melancholy facts in history" (Jahn 2005a, p. 603). While on the one hand civilised nations face the dangers of backward development and stagnation on the other, savage and barbarian peoples lack the very faculties to develop and progress independently and without the influence of a foreign, 'civilising' force. As such, it becomes the responsibility of civilised peoples to compel the savage and barbarian nations to change and move towards progress. As this can only be achieved through force, despotism becomes the most appropriate form of rule for savages, barbarians and semi-barbarous peoples (Jahn 2005b, p. 196). There are clear tones of what can 
only be categorised as condescending paternalism and 'the white man's burden' in Mill's liberal philosophy, which asserts that, "despotism is a legitimate mode of government in dealing with barbarians, provided the end be their improvement [my emphasis], and the means justified by actually effecting that end" (Mill 2005, p. 14). In short for Mill, "barbarians have no rights as a nation, except a right to such treatment as may, at the earliest possible period, fit them for becoming one" (Mill as quoted in Jahn 2005a, p. 605).

Indeed, a close inspection of Mill's philosophy of history and international affairs makes it clear that he is an advocate of what Pitts terms as "a despotic, but civilising, imperial rule" or a "progressive colonial despotism" (Pitts 2005, p. 133, p. 136). Jahn outlines how Mill's philosophy, which on the basis of establishing a clear moral and political hierarchy between civilised and barbarian peoples, essentially makes a case against extending the rights of sovereignty and non-intervention to barbarian nations, is clearly echoed in contemporary liberal thought and, more significantly for this paper, in the liberal rhetoric surrounding the GWoT as well. Firstly, Jahn argues, "non-liberal or 'outlaw states' are defined by their refusal of comply with international law" - in other words, their refusal to reciprocate based on which they can then be "denied the right to sovereignty and non-intervention". Second, he argues that, "intervention is an appropriate means to speed up the development of 'all peoples', who will be 'safer and more secure' once the sources of 'aggressive and dangerous behaviour' are removed” (Jahn 2005b, p. 197) ${ }^{16}$. In short, Mill's philosophy makes a fairly robust case for inequality and aggressive (if paternalistic and civilising) intervention in the affairs of those categorised as barbarian 'others' in order to further, what would in contemporary liberal thinking be categorised as, the democratic peace. Taken together, the impact and influence exerted by the philosophies and worldviews of Kant and Mill upon US politicians, domestic and foreign policy should not be underestimated ${ }^{17}$.

\section{From 'Offensive Liberal Wars' of Choice to 'Defensive Liberal Wars' of Necessity}

16 Jahn also outlines that the key difference between Mill and contemporary liberals lies in the disinclination of the latter to exercise a form of 'colonial rule' over what they see as barbarian, i.e. non-liberal or outlaw states/people. He also draws clear parallels between Mill's conception of 'civilisation' and the contemporary liberals' conception of 'regime type'.

17 It is worth noting that obviously other philosophers have also exerted influence on US foreign policy - Locke, Paine and Burke to name just a few. However, given that tracing the philosophical evolution of US foreign policy is not the key purpose of this essay only Kant and Mill are addressed as being (arguably) the most relevant for its purposes.

${ }^{18}$ Due to limitations of space and this article's particular focus I deliberately concentrate upon the liberal
Having traced some of the historical philosophical influences on contemporary US foreign policy, I now turn to understanding the place of the GWoT in the broader trajectory of American behaviour in the international system. Here it is clear that the United States has been preoccupied with establishing international peace and stability through the promotion of liberal democracy, through the use military force if necessary, at least since the twentieth century ${ }^{18}$. There is little doubt that US foreign policy has been shaped by its belief in the significance of not only adhering to liberal democratic values but also a perceived obligation to spreading these values and norms internationally. Tony Smith states that, "the most consistent tradition in American foreign policy has been the belief that the nation's security is best protected by the expansion of democracy worldwide" (Smith 1993, p. 9). Jonathan Monten in turn argues that the "concept of the United States as agent of historical transformation and liberal change in the international system informs almost the entire history of US foreign policy and democracy promotion is not just another foreign policy instrument or idealist diversion; it is central to US political identity and sense of national purpose" (Monten 2005, p. 113). In this regard, the GWoT may be viewed as but an extension of what in essence has been a historical US practice of democratisation conducted to ensure both its national security and perceived survival in what is a hierarchical and dangerous international system ${ }^{19}$.

There were various efforts in the $20^{\text {th }}$ century to spread the values of liberalism by exporting democracy to countries that had hitherto been ruled by dictators and authoritarian regimes. A large number of these efforts were promoted by the United States and backed by the use of U.S. military force (Kurth 2005, 
tendencies in US foreign policy. However, this should not suggest an uncomplicated generalisation of US foreign policy as 'liberal' in the long term. For a rich, complex picture that depicts various traditions in US foreign policy - Jacksonian, Jeffersonian, Hamiltonian, Wilsonian etc. that have pulled US policy in different, at times contradictory directions, see for example Mead (2002). ${ }^{19}$ One can argue that there has been a broad agreement to some extent on what Monten terms "the moral and strategic objectives" of US foreign policy, which cuts across political divisions. The debate has tended to focus on the "policy means with which to prosecute that mission" (Monten 2005, p. 114). More on this later.

${ }^{20}$ See also Boot (2003) and Linn (1989). p. 306). In fact, the $20^{\text {th }}$ century began with the United States engaging in three separate military interventions aimed at bringing democracy to the former Spanish colonies of the Philippines, Cuba and Puerto Rico (Kurth 2004; 2005). More significantly, not all of these interventions were conducted without sustaining significant losses. For instance, the U.S. military intervention in the Philippines from 1899-1902, with its bloody repression of the local insurgency, not only resulted in the loss of around four thousand U.S. soldiers but also resulted in the deaths of 16,000 Filipino guerrillas and as many as 200,000 civilians (Kurth 2005, p. 306) ${ }^{20}$. This paternalistic trend of democracy promotion was further strengthened by President Woodrow Wilson who first sent the U.S. Marines into several Latin American countries in order to "teach the Latin Americans to elect good men," and then sent in U.S. troops into Europe stating that the United States was going to "make the world safe for democracy" (Kurth 2005, p. 306). Indeed, as Wilson stressed, “America would spend her blood and her might for the principles that gave her birth and happiness" (Woodrow Wilson as quoted in Kaplan 2003, p. 22). James Kurth identifies four theatres where the United States has used military conquest and occupation to bring about political democratization.

"(1) the Caribbean basin and Central America from the 1900s-1930s (Cuba, the
Dominican Republic, Haiti, and Nicaragua) and again from the 1960s-1990s (the
Dominican Republic and Haiti again and also Grenada and Panama); (2) Central
Europe from the 1940s-1950s (West Germany, Austria, and Italy); (3) Northeast
Asia from the 1940s-1950s (Japan and South Korea); and (4) Southeast Asia
from the 1960s-1970s (particularly South Vietnam). Together, these add up to
more than a dozen cases in which the United States has used military occupation
to bring about political democratization. They provide useful precedents and les-
sons for the [...] efforts in Iraq" (idem, pp. 306-307).

In other words, the use of military force by the United States for the cause of democracy promotion is not a new phenomenon and, at least empirically, one can argue that it has been a benchmark of American foreign policy in the $20^{\text {th }}$ century. It is however worth noting that that the United States has had distinctly different approaches to fostering democracy in Europe vs. the Western Hemisphere, perhaps best illustrated by US policy under President Woodrow Wilson. For most people, it is Wilson's European policy that was enacted "mainly through international agreements and organisations" (Smith 1993, p. 62) that represents what has come to be known as 'Wilsonianism'. However, this perspective seems to forget the hard, militaristic, unilateral stance that the US chose to adopt in its dealings with Latin America in their efforts to teach them to 'elect good men' (Desch 2007, p. 19). Wilson's belief in America's role in spreading liberal values and norms is evident when he declared in 1912, "I believe that God has planted in us visions of liberty [...] that we are chosen and prominently chosen to show the way to the nations of the world how they shall walk in the path of liberty" (Williams 2006, p. 3). This stance is a clear illustration of how the Kantian notion of the democracy promotion and the Millean notion of the 'barbarian nation' and a 'hierarchical' international system have translated into the practices of US foreign policy.

At the same time, as mentioned above this was by no means a temporary or passing phase of US foreign policy. Instead, the "legacy of Wilson the democratic crusader was passed down from generation to generation - from Harry Truman, who argued that 'totalitarian regimes undermine the foundations of international peace and hence the security of the United States', to John. F. Kennedy - before being put to rest [I would argue with the benefit of hindsight, temporarily] in the jungles of Vietnam" (Kaplan 2003, p. 22). By the end of the Cold War, US armed interventions had evolved quite significantly, at least in material terms. By this period, the use of force could be relatively controlled thanks to the advent of precision technologies (Freedman 2006b). Freedman ar- 
gues that the direct result of this technological evolution was that there were fewer Western and civilian casualties than before. Even so, an inherent tension within liberal thinking remained as an instinctive distaste for the use of military force on part of non-interventionist liberals clashed with the interventionists' crusader-like tendency to actively champion the cause of justice and protect the oppressed internationally through a vigorous promotion and promulgation of liberal norms and values (more on this below). Freedman makes a case that to some extent this tension appeared manageable in the armed interventions of the 1990s, which were undertaken to "protect the weak, shelter the poor and feed the hungry" (Freedman 2006a, p. 51). He argues rather eloquently, that these interventions of the 1990s had less to do with Western interests than with Western sensibilities in the face of tremendous violence and human suffering. Although they tended to be conducted in the most part, rather reluctantly and somewhat tentatively and they produced somewhat mixed results - in humanitarian terms they most certainly made a difference. However, the key difficulty lay in creating stable political conditions in the wake of armed intervention that would allow Western forces to withdraw. In this, armed intervention proved to be a way of "thwarting a slide into hell but not too suited to grasping heaven" (idem, pp. 51-52).

Nonetheless, irrespective of the consequences of intervention, what is worth noting is that, as Freedman argues, these interventions were largely 'wars of choice', i.e. they were altruistic rather than necessary for the interveners. I would argue that the same case might be made for the interventions in Latin America and to some extent also in Vietnam. In this sense, these interventions were 'offensive liberal wars', because they sought to aggressively extend liberal values and freedoms "to places where they were [...] absent, or at least in short supply" (ibidem). Philosophically grounded in the Kantian logic of an ever-extending pacific federation these were wars that were fought to ensure national security, and eventually a state of 'perpetual peace'. It is significant that these wars tended to be waged when resources were available and tapered off when resources became scarce - clear reflections of how these were an exercise in 'choice' (idem, p. 63). Furthermore, these were wars fought for justice with little, if any, regard for context (idem, p. 65), very much in line with Mill's philosophy of protecting and accelerating the development of 'all peoples" through civilising, albeit aggressive and imperialistic, intervention (Jahn 2005b, p. 197).

In sharp contrast, Freedman categorises the wars fought in Afghanistan and Iraq under the rubric of the 'Global War on Terror' as 'defensive liberal wars', i.e. wars of necessity, fought to ensure survival, to defend and preserve the Western way of life. He argues that "because [these interventions] were strategically defensive, they took on the character of wars of necessity, [...] [where] no semblance of defeat could be tolerated. This meant that not only were the methods offensive, in that the war was taken into enemy territory; they were also less restrained than the interventions of the 1990s. In both cases the objectives also took on a more offensive aspect, as they came to involve an attempt to bring the Western way of life to brutalised countries" (Freedman 2006a, p. 52). One can argue that even these 'offensive wars' to some degree echoed the Wilsonian logic by seeking not only to guarantee national security by making 'the world safe for democracy' but also attempting to 'teach the Afghans and Iraqis to elect good men'. Thus, not only was exporting liberty to the oppressed of Afghanistan and Iraq presented as a "great moral cause" it was framed as merely the beginning of a campaign that (much in same vein as Woodrow Wilson) aimed to "bring the hope of democracy [...] to every corner of the world" (George W. Bush as quoted in Kaplan 2003, p. 21). What was different here however was that this was now an imperative, framed as essential for the survival of the nation. As such, while these wars of necessity had to be fought irre- 
spective of resources and were criticised by opponents for the "simplistic presentation and the exaggerated role claimed for armed forces in their prosecution" (Freedman 2006a, p. 52), they were by no means bereft of America's traditional liberal aspirations. Thus, US armed 'interventions' post- 9/11 in Afghanistan and Iraq, marked a key shift in the policies of a liberal state that had for much of its history only undertaken offensive liberal wars of choice. The United States, in launching the GWoT, was ostensibly defending its right to survival against illiberal regimes and ideologies that challenged its political, social and economic principles. Somewhat paradoxically then, as per Freedman's argument, defensive liberal wars not only needed to focus on context, they also tended to be more aggressive/offensive in their means and aims as the stakes were higher ${ }^{21}$. As Desch argues then, what makes the GWoT so dangerous and impels the United States towards the use of illiberal tactics is not so much the physical threat that transnational terrorism or Al Qaeda pose to the homeland, but rather the existential threat they pose to the American way of life. However, were it not for the deeply rooted liberal tradition within in the United States it would, in all likelihood, "view the threat from global terrorism in a less alarmist light (more akin to a chronic crime problem than to World War IV) and would adopt more restrained policies in response (i.e. containment rather than global transformation)" (Desch 2007, p. 8).

\section{Interventionist liberals and interventionist neoconservatives: old bedfellows}

${ }^{21}$ This is a very important nuance and stands in direct contrast to Benjamin Miller's conception of 'defensive liberalism' and 'offensive liberalism' that he outlines in his article (Miller 2010). Miller associates defensive liberalism with Kant's 'evolutionary liberalism' and sees it as anti-militaristic/anti-interventi onist, pro-international institutions and focussed on the multilateral use of both soft and hard power. In contrast, offensive (or Thomas Paine's revolutionary) liberalism is categorised as reliant upon the "assumed pacifying tendencies of democratisation, displaying a regular willingness to consider the use of force towards that objective" (idem, p. 566)

${ }^{22}$ See also Pitts (2005).
Andrew Williams argues that, "what distinguishes liberal states from their illiberal counterparts is that they [i.e. liberal states] believe quite sincerely in the creation of a better world and that they are exemplars of what the world should look like" (Williams 2006, p. 5). There are some differences however regarding how this vision of creating a better world should be translated into practice, perhaps best encapsulated in Jonathan Monten's broad categorisation of exemplarism and vindicationism. Monten argues that the exemplarism tradition of US liberalism believes that democracy and liberal values can be spread by example while the tradition of vindicationism believes that a more activist foreign policy is necessary to accomplish this (Monten 2005) ${ }^{22}$. Put another way, Monten essentially categorises the US liberal tradition as leaning either towards military interventionism or non-interventionism. He also rightly asserts that while both these approaches have coexisted in American political history, there have certainly been times when one has been more prevalent than the other (Pitts 2005, p. 114). Based on such a categorisation, there seems to be more than just a passing resemblance between the neo-conservatives and the Wilsonian (or interventionist) liberals as regards their beliefs about intervention and democratisation. This is a good basis to comprehend not only the somewhat startling similarity between George W. Bush and Woodrow Wilson but also the deeply illiberal policies adopted by both during their respective presidencies.

Many scholars have remarked upon this similarity between George W. Bush and the neoconservatives and the liberal traditions of the United States as exemplified by Wilsonianism. Lawrence Kaplan wrote in 2003 that, "Bush is becoming the most Wilsonian president since Wilson himself" and "the influence of Wilsonian ideals may be gleaned in everything from the administration's plans to use Iraq as a pivot for democratising the Arab world to its broader strategy of transforming rather than coexisting with totalitarian regimes" (Kaplan 2003, p. 21). Indeed, many of the views that are associated with the neoconservatives today echo those of Woodrow Wilson who believed that American power could and should be used to promote justice and democracy internationally and that by reshaping the world, America would secure its political and security interests. 
${ }^{23}$ It is also worth noting that authors like Monten also clearly point out how by the time we get to the Bush Doctrine, neoconservative thinking had evolved considerably, so much so that it now clearly corroborated the basic realist "hypothesis that variation in political expansion is a function of relative changes in material capabilities" (Monten 2005, p. 143)

${ }^{24}$ It is worth noting that a small minority of authors, e.g. Caverley (2010), do not equate neo-conservatism with liberalism. Instead pointing to its distinctly illiberal elements, including the very un-Kantian trait of unilateralism, they argue it is more akin to a hegemonic form of neo-classical realism, among others using raw power to impose a form of government conducive to American interests. Again, I would like to thank my anonymous reviewer for pointing this out.

${ }^{25}$ Freeman argues that the "propensity to exaggerate threats to national security, and to insist on high levels of defence preparedness, may be an enduring characteristic of neo-conservatism, which gives it a natural point of contact with more traditional conservatism" (Freedman 2005, p. 100).

${ }^{26}$ See also Desch (2001) and Kennedy (2005). Of course, another key difference between the liberals and the neoconservatives is their perspective on the role of
Proponents of this view also argue that a key requirement of a Wilsonian foreign policy is not only the desire to reshape the world and mould events, but also a conviction that the United States possesses the power and ability to do so - which also explains why this "Wilsonian impulse has ebbed and flowed" in American politics and possibly also why it remerged with the neoconservatives (Steel 2003, p. 21). But this ideological continuity is perhaps not surprising given that the origins of neo-conservatism in the United States are liberal, lying as they do in the response by a group of Cold War liberal democrats and democratic socialists who, in the 1970s, opposed the utopianism of antipoverty programmes and affirmative action domestically and the policy of détente with the Soviet Union abroad. Instead these neoconservatives, as they came to be known, argued for a foreign policy that not only could curb the spread of communism but also actively promote democracy in the international system as a mechanism to secure United States' economic and strategic security. However, it is imperative to note that while it may have had reactionary liberal roots and despite some obvious similarities with Wilsonianism, over time American neo-conservatism has come to "embody a distinctive and somewhat coherent set of causal and normative beliefs organised around the assertion of US military strength, resolve and political values" (Monten 2005, pp. 142-143) ${ }^{23}$. In this regard, and thanks to the unapologetic desire to channel US power to affect democratic change in the international system, neo-conservatism can be firmly situated within the long liberal tradition of 'vindicationism'24.

Where the neoconservatives differ from traditional liberal interventionists is in their emphasis on the centrality of US military power as the primary instrument to engender liberal change and generate a 'new world order' - and this became amply clear over the course of the $\mathrm{GWoT}^{25}$. It is because of this that Ronald Steel argues that,

"Liberals and neoconservatives may both be correct in considering themselves to be Wilsonians. In truth, they are more alike than they admit in their ideological ambitions and their moral justifications [...] In practice the difference between interventionist liberals and interventionist neoconservatives is more a matter of degree than of principle. It rests on how much exercise of military power the liberals will rationalise and how much deference to liberal clichés the neoconservatives will tolerate" (Steel 2003, p. 20) ${ }^{26}$.

At the same time, the transformative impulse for neo-conservatism also relies upon a sincere belief in US capabilities to affect liberal change abroad, which is in turn based upon an urgent acknowledgement of both its remarkable post-Cold War military primacy as well as its unrivalled position of power in the unipolar international system. Strategically then, the GWoT must also be understood as an attempt by neoconservatives to use America's position as the world's sole superpower to secure an unmatched position of advantage in the international system. In other words, the GWoT represents a culmination of the historical neoconservative call for using force to check the emergence of potential challengers to US predominance. It is worth noting that in the post-Cold War period, the neoconservatives viewed traditional balance of power strategies as both unnecessary and unsuitable for what they argued were radically different circumstances. It was widely acknowledged, and not solely by the neoconservatives, that ongoing system-level changes meant that the United States could not expect to remain the sole superpower in the world forever. This was then America's "unipolar moment" 27 and the neoconservatives (as well as various other US administrations, including those of George W.H. Bush and Bill Clinton) argued that it was imperative that the United States take advantage of its position to both preserve and extend its hegemony in the international system. The resulting realignment in US foreign policy, most ostensibly reflected in America's gradual but steady shift away from multilateralism back towards a 
international institutions in foreign policy. Thus, many liberals believe that foreign policy is best conducted multilaterally through international institutions while neoconservatives tend to be clearly more unilateralist (Desch 2007).

27 See Ehrenberg et al. (2010) and Krauthammer (1990).

28 This was seen in the US abandonment of institutional cooperation and established multilateral strategies such as alliance building and the tactical use of sanctions. See also Singh (2012).
${ }^{29}$ See Kagan (2002; 2003) and Reus-Smit (2004). more unilateralist tendency, came to be both enthusiastically embraced and fully operationalised by the neoconservatives in George W. Bush's administration $^{28}$.

The (re)emergence of an aggressive interventionist policy post-9/11 with the GWoT, can also be understood by viewing the historical evolution of American self-identity through the lens of 'exceptionalism', or the perception that the Unites States differs "qualitatively from other developed nations, because of its unique origins, national credo, historical evolution and distinctive political and religious institutions" (Harold Hongju Koh as quoted in Monten 2005, p. 119). In foreign policy terms, exceptionalism translates into a belief that "liberal values transfer readily to foreign affairs" and thus bolsters the US tendency to attempt to both 'remake' international society and (re)assert its right to be different by taking "individual action against threats" (Buzan 2004a). Hassner argues that, "exceptionalism carries with it a tendency to consider that the United States is empowered, because of the purity of its intentions and the excellence of its regime, to judge between good and evil, to award others good or bad points, to punish the wicked and troublemakers, not to recognize any superior legal authority above that which comes from the American people themselves, and to consider any external inclination to cast doubt on American intentions or to apply to it the criteria that it applies to others as an insult" (Buzan 2004b, p. 155). Thus, inherent in exceptionalism is not only a clear notion of what it means to be American but also the rights, responsibilities and threats that come with being the United States. The fact that, threats are framed as exceptional is crucial to understanding how the rhetoric of the GWoT not only constructed 9/11 as exceptional but also how this notion of exceptionalism, itself rooted in a very particular vision of the United States' mission abroad, enabled a successful securitisation of Al Qaeda and transnational terrorism by the neoconservatives.

As stated above, the discourse of the GWoT underscored the exceptional nature of the USA and, in doing so, provides us with critical insights into the United States' particular understanding of its role, position and privileges in the post-9/11, unipolar world. First, the discourse of the GWoT framed 9/11 as an exceptional act and a national tragedy. America was attacked because it was America, because it was "the brightest beacon for freedom and opportunity in the world" (Bush 2001a). In constructing 9/11 as an exceptional act of violence this discourse (re)established that, as the sole superpower, the United States not only enjoyed the advantage of exceptional powers and privileges in the international system but also attracted exceptional threats. As the focus of both "myriad resentments and the bearer of great responsibilities" (Derian 2002, p. 103) it was obliged to secure itself, not only because it had to but also because it could $^{29}$. Of course, as stated previously, the United States' perceptions of threat and insecurity were essentially rooted in not only the structural pressures generated by the post-Cold War unipolar system (Buzan 2004a) but also bolstered by a long foreign policy tradition which believed that US national security was best protected by the expansion of democracy. More crucially, the promotion of democracy and liberal change in the international system, as explained above, has been a central component of American political identity. Thus when these factors combined, they not only elevated America's perceptions of the threats it was exposed to but also complemented elements of its exceptionalism. Thus, America's propensity towards hypersecuritisation i.e., its "tendency to both exaggerate threats and resort to excessive countermeasures" (idem, p. 18) already underway due to conditions of unipolarity, was further intensified by the attacks of 9/11. To underscore once more, this hypersecuritisation was rooted very particularly in a liberal view of the world - i.e. in the notion that Al Qaeda represented an existential threat to key liberal values and freedoms in the interna- 
tional system. As a result, not only did this vision predispose the United States towards adopting an aggressive, unilateralist response to $9 / 11$, but the universalist element of American exceptionalism also meant that it "could justify the pursuit of its own national security not just on the basis of preserving a distinctive nation [...] but also on the basis of protecting the future wellbeing and rights of all of humankind" (idem, p. 18). As Steel so eloquently puts it, "in seeking virtuous ends, they [i.e. the United States] embrace[ed] questionable means". (Steel 2003, p. 21). In short, the interplay between unipolarity and universalist aspects of American exceptionalism enabled the United States to both claim special rights and privileges in pursuit of its national security (Buzan 2004a, pp. 18-20) and special (albeit illiberal) means to achieve the same. Thus, in constructing 9/11 as exceptional the Bush administration not only underscored the unique and privileged status of the US but also justified illiberal policy under the GWoT as the legitimate and necessary response of an exceptional nation-state.

\section{The themes of the neoconservative GWoT discourse - in defence of liberal values and freedoms:}

${ }^{30}$ President Bush and the 2002 National Security Strategy as referred to and/or quoted in (Dunne 2009, p. 110). An interesting point to note regarding the influence exerted by Deputy Secretary of Defence, Paul Wolfowitz and his fellow neoconservatives on US foreign and security policy is highlighted by Kaplan who states that Wolfowitz's lectures on democracy were "embedded - almost verbatim - in the president's National Security Strategy" (Kaplan 2003, p. 3).
The securitisation of a Western way of life as exemplified by its liberal values and freedoms is clearly operationalised in the speeches and communications that emerge from the Bush administration from 2001-2008, in which Al Qaeda's brand of international terrorism is progressively and successfully framed as an existential threat. Indeed, even a brief purview of the communications that emerged during this period reveal that the Bush administration's foreign and security policies were essentially rooted in liberal concerns and principles. Bush's 2004 State of the Union address asserted that the aim of the United States was "a democratic peace". Similarly, the 2002 National Security Strategy "was framed by the desire to protect and extend liberty - even including the enigmatic goal of achieving a "balance of power that favours freedom" " 30 . In examining the communications produced during the Bush administrations, especially his annual State of the Union addresses, the philosophical and political influences of Kant, Mill as well as Wilson are amply evident. Moreover, it is also clear how this discourse deliberately a) framed Al Qaeda as an existential threat to liberal values and freedoms and as such the Western way of life, and b) positioned the United States as a defender of these values in the international system. Certain key themes emerge in the securitisation rhetoric and can be located in almost all the documents studied. Upon closer examination these themes clearly constitute a step-by-step construction of a case for waging a defensive liberal war, that encompassed not only preventive military action and intervention but also had at its core the clear aim of democratising what were seen as backward and barbaric and societies, for the sake of US national security. In other words, what we see is in these communications is the systematic construction of the case, couched in Kantian, Millean and Wilsonian language, for armed intervention in first Afghanistan and then Iraq.

\section{VI.1. Theme I: The presence of imminent danger from illiberal regimes and ideologies}

The regimes of Afghanistan and Iraq as well as both their and Al Qaeda's ideologies are represented in these communications as the very anti-thesis of civilisation and the civilised. They are commonly described, either directly or indirectly, using very Millean language and concepts such as 'barbaric', 'evil', 'brutal' and 'irrational' and more significantly, as inherently violent. As Bush states in his 2002 State of the Union address: "We have seen the depth of our enemies' hatred in videos where they laugh about the loss of innocent life [my emphasis]. And the depth of their hatred is equalled by the madness of the destruction they design [my emphasis]" (Bush 2002). At the same time, the idea 
that traditional mechanisms of engagement are useless against this new, innovative and frighteningly irrational and destructive enemy is also clear in this discourse. For instance, the Bush administration's 2002 National Security Strategy states how "traditional concepts of deterrence will not work against a terrorist enemy whose avowed tactics are wanton destruction and the targeting of innocents; whose so-called soldiers seek martyrdom in death and whose most potent protection is statelessness" (United States 2002). Vice President Dick Cheney echoed these words when he asserted that a group like Al Qaeda "cannot be held back by deterrence, nor reasoned with through diplomacy" (Cheney 2002). In other words, countries and groups identified as enemies in the GWoT are framed by the discourse, as peoples with whom alliance or negotiation is impossible because, as Mill argues, alliances require reciprocity that barbarians, given that they cannot be relied on to observe rules, are incapable of. Indeed, Bush underscored this blatant flaunting of established norms and rules when he reminded us how Al Qaeda had, in targeting the civilian population of the United States, directly violated "one of the principle norms of the law of warfare" (United States 2002). Al Qaeda, its allies and the nations that support them are thus framed as 'unjust enemies' in this discourse and this is underscored by constant references to their deliberate targeting and brutalisation of both their own people as well as international civilian populations (more on this below).

These groups and nations are also represented as posing a direct threat to US national security given that they are engaged in plotting the destruction and downfall of the 'West' in general, and of the United States, in particular. Hence Bush argues, "We have found diagrams of American nuclear power plants and public water facilities, detailed instructions for making chemical weapons, surveillance maps of American cities, and thorough descriptions of landmarks in America and throughout the world" (idem). The shadowy nature of transnational groups makes them all the more threatening because it challenges the United States' traditional military capabilities and undeniable technological superiority. President Bush underscores this evolving and acute threat to national security when he asserts how "enemies in the past needed great armies and great industrial capabilities to endanger America. Now, shadowy networks of individuals can bring great chaos and suffering to our shores for less than it costs to purchase a single tank. Terrorists are organized to penetrate open societies and to turn the power of modern technologies against us" (idem).

Some key words used in this discourse include repeated references to 'evil' indeed one could argue that this word is almost overused in communications from this period. Several variations of 'kill' and 'murder' are also common. Dangers, chaos and wars are constantly referred to and then given concrete form through references to terrorists and terrorism, 9/11, Chemical, Biological, Radiological and Nuclear Weapons (CBRNs) and Weapons of Mass Destruction (WMDs). These themes can be found repeatedly in statements, for example Bush's 2006 State of the Union address:

"Terrorists like bin Laden are serious about mass murder, and all of us must take their declared intentions seriously. They seek to impose a heartless system of totalitarian control throughout the Middle East and arm themselves with weapons of mass murder. Their aim is to seize power in Iraq and use it as a safe haven to launch attacks against America and the world. Lacking the military strength to challenge us directly, the terrorists have chosen the weapon of fear. When they murder children at a school in Beslan or blow up commuters in London or behead a bound captive, the terrorists hope these horrors will break our will, allowing the violent to inherit the Earth. But they have miscalculated: We love our freedom, and we will fight to keep it" (Bush 2006).

Closely tied into this depiction of the terrorist 'others' is the logic that the dangerous and illiberal regimes and ideologies associated with them must be 
dismantled/disarmed in order to prevent them from attacking and destroying the Western way of life. Thus, a clear association is made between the non-state attackers of 9/11 with what is, in essence, a state-based preventive response. Furthermore, repeated references are made to states that either collude with radical Islamists by proving safe havens, financial and military support or turn a blind eye to these radical groups while simultaneously representing a threat in their own right to the safety and wellbeing of the United States and its citizens. The discourse also references the Kantian idea that these are repressive, non-representative states, essentially controlled by regimes that violate citizen rights and reject the basic principles of democracy. As such these states are framed as a threat to the 'pacific federation' and so it becomes the United States' responsibility to neutralise the threat and preserve liberal values in the international system. What is key to note here is the coalescing of multiple different threats into one large threat, which the United States ignores at its own peril. The message is clear: the United States must not shirk its liberal responsibilities but instead, once again, fight for the freedoms, values and way of life of all civilised peoples. In short, it must take military action to secure not only national and international security but also human security.

"Today, the gravest danger in the war on terror, the gravest danger facing America and the world, is outlaw regimes that seek and possess nuclear, chemical, and biological weapons. These regimes could use such weapons for blackmail, terror, and mass murder. They could also give or sell those weapons to terrorist allies, who would use them without the least hesitation. This threat is new. America's duty is familiar. Throughout the 20th century, small groups of men seized control of great nations, built armies and arsenals, and set out to dominate the weak and intimidate the world. In each case, their ambitions of cruelty and murder had no limit. In each case, the ambitions of Hitlerism, militarism, and communism were defeated by the will of free peoples, by the strength of great alliances, and by the might of the United States of America" (Bush 2003a).

\section{VI.2. Theme II: U.S. responsibility to protect its citizens and its way of life}

A second theme that emerges is the United States' responsibility towards its own citizens and way of life. The idea projected here is that of establishing a system of security that cannot be breached. This not only references the American aim of strengthening internal security but also protecting the homeland by 'taking the war to the enemy' so that the 'enemy does not come to our shores'. This is very much in line with Freedman's logic of the necessary, defensive war that adopts offensive means and takes the fight to the enemy. More significantly, once again it is about highlighting the particularly responsibility of the US hegemon to secure national security, not by retreating within its own borders but by looking outward and guaranteeing its foreign policy interests in the international system.

\footnotetext{
"In a time of testing, we cannot find security by abandoning our commitments and retreating within our borders. If we were to leave these vicious attackers alone, they would not leave us alone. They would simply move the battlefield to our own shores. There is no peace in retreat, and there is no honor in retreat. By allowing radical Islam to work its will, by leaving an assaulted world to fend for itself, we would signal to all that we no longer believe in our own ideals or even in our own courage. But our enemies and our friends can be certain: The United States will not retreat from the world, and we will never surrender to evil" (Bush 2006).
}

The neoconservative assumption that becomes evident in this discourse is that in the process of protecting its own citizens and acting in its own interests the United States also serves the interests of the international system. For instance, according to Condoleezza Rice, "America's pursuit of the national interest will create conditions that promote freedom, markets, and peace. Its pursuit 
of national interests after World War II led to a more prosperous and democratic world. This can happen again" (Rice 2000). In other words, not only is the US pursuit of its national interests legitimate, it is also virtuous (Monten 2005, p. 148). This connection between national and international security as well as the link between security and liberal values is repeatedly emphasised. For instance, Bush stated, "I believe we have a responsibility to promote freedom that is as solemn as the responsibility is to protecting the American people, because the two go hand in hand" (George W. Bush as quoted in Desch 2007, p. 22). Clearly evident in this logic is not only an assertion of the concept of the United States as an agent of historical transformation and liberal change in the international system but also democracy promotion as central to US political identity and sense of national purpose. Thus, President Bush stated in 2005 that, "America's vital interests and our deepest beliefs are now one” (Bush 2005b).

Further woven into this sense of responsibility towards US citizens is the theme of sacrifice for the honour and protection of the nation state. This is used primarily in reference to the military and other service officials - such as the fire fighters - involved in counter-terror operations and/or military interventions. Also clearly underscored in this discourse is the incredible spectrum of risks confronting the American nation - from biological and chemical weapon attacks to more conventional terrorism.

\begin{abstract}
"In the three and a half years since September the 11th, 2001, we have taken unprecedented actions to protect Americans. We've created a new Department of Government to defend our homeland, focused the FBI on preventing terrorism, begun to reform our intelligence agencies, broken up terror cells across the country, expanded research on defenses against biological and chemical attack, improved border security, and trained more than a half million first-responders. Police and fire fighters, air marshals, researchers, and so many others are working every day to make our homeland safer" (Bush 2005a).
\end{abstract}

VI.3. Theme III: U.S. responsibility towards international security and its allies

A historic sense of leadership comes through very clearly in the discourse of the GWoT that consistently underscores that this leadership role entails that the United States help maintain security for its allies and friends. Implicit in this historical responsibility of democracy promotion is a normative sense of rightness, superiority, confidence as well as the "assumption that democracy is a universal system” (Monten 2005, p. 145). Thus, Bush’s 2002 National Security Strategy asserted how American power could be used to create "conditions in which all nations and societies can chose for themselves the rewards and challenges of political and economic liberty" (United States 2002). He also stated in 2006 how:

"America rejects the false comfort of isolationism. We are the nation that saved liberty in Europe and liberated death camps and helped raise up democracies and faced down an evil empire. Once again, we accept the call of history to deliver the oppressed and move this world toward peace" (Bush 2006).

This notion that the United States was acting on behalf of not only national but also international interests is, as highlighted above, repeatedly alluded to in the discourse. However, the discourse does not stop at making the connection between national and international security and between security and liberal values. Instead it develops this idea into a full-fledged national responsibility to defend the reputation and credibility of international allies and organisations, with the use of military force if necessary. For instance, a number of decision makers believed that it was imperative that the US rises up to the challenge of defending the "credibility of the United Nations" (Monten 2005, p. 148). Rice argued in 2003 with reference to Saddam Hussein and the weapons of mass de- 
${ }^{31}$ Monten rightly points out that in assuming for the UN the defence of its credibility, the US empowered itself to "pursue those interests at its unilateral discretion, not constrained by the withholding of consent by the organization itself". struction inspections process, "It isn't American credibility on the line, it is the credibility of everybody that this gangster can yet again beat the international system" and in allowing Iraq "to play volleyball with the international community this way will come back to haunt us someday. That is the reason [to invade] [...] Iraq is critical to re-establishing the bona fides of the Security Council" (Condoleezza Rice as quoted in Monten 2005, p. 148) ${ }^{31}$. But the idea of defending credibility did not apply to international allies alone - the same ideals held true for the United States as well. Thus, credibility was the very foundation upon which the spread of liberal values rested. The logic was that the US discourse of promoting its political values in the international system had to be backed by a willing and demonstrable use of its material power to implement this liberal change when necessary. Thus as Rice stated in 2004, "president Bush's foreign policy is a bold new vision that draws inspiration from the ideas that have guided American foreign policy at its best: That democracies must never lack the will or the means to meet and defeat freedom's enemies, that America's power and purpose must be used to defend freedom, and that the spread of democracy leads to lasting peace" (Rice 2004). In other words, the US had to have the will to put its money where its mouth was. This was more than evident in the manner that the WMD-related concessions by Libya were construed as the outcome of a post-Iraq renewal of US credibility in the international system. Bush essentially underscored this stance in his 2004 State of the Union address, when he stated: "nine months of intense negotiations succeeded with Libya, while twelve years of diplomacy with Iraq did not [...]. Words must be credible, and no one can now doubt the word of America" (George W. Bush as quoted in Monten 2005, p. 148).

Closely tied into this idea of responsibility was America's self-image as a hegemon and a beacon of hope, freedom and liberal values. Hence, as Bush asserted, "I believe that the United States is the beacon for freedom in the world" (George W. Bush as quoted in Desch 2007, p. 22). These liberal values and freedoms are necessary to lead the 'pacific federation' by setting an example that can be emulated by its allies and imposed forcibly if necessary upon other, non-liberal nations - of course, for their own good. This is very clearly in the Millean vein of 'barbarians' having "no rights as a nation, except a right to such treatment as may, at the earliest possible period, fit them for becoming one". In other words, America's responsibility lay not only in securing national and international security but also in creating a new liberal, democratic world order (Mill as quoted in Jahn 2005a, p. 605).

\footnotetext{
"But America will always stand firm for the nonnegotiable demands of human dignity: the rule of law; limits on the power of the state; respect for women; private property; free speech; equal justice; and religious tolerance. America will take the side of brave men and women who advocate these values around the world, including the Islamic world, because we have a greater objective than eliminating threats and containing resentment. We seek a just and peaceful world beyond the war on terror" (Bush 2002).
}

Constant references are made to this union of like-minded states and allies words used here are coalition, allies and these are presented as upholding liberal values - respecting individual rights and freedoms - as opposed to the barbaric, brutal and oppressive regimes that they are opposing. Clearly Millean language is used as alliances are framed as being composed of like-minded, i.e. 'civilised', nations.

\footnotetext{
"In this moment of opportunity, a common danger is erasing old rivalries. America is working with Russia and China and India, in ways we have never before, to achieve peace and prosperity. In every region, free markets and free trade and free societies are proving their power to lift lives. Together with friends and al-
} 
lies from Europe to Asia and Africa to Latin America, we will demonstrate that the forces of terror cannot stop the momentum of freedom" (idem).

Moreover, as the United States defends and extends liberal values in the international system these allies also come to include non-Western nations such as Afghanistan whose new leaders, in stark contrast to the barbarian 'other' (i.e. the Taliban), crave the establishment of democratic governments and institutions. Here while the United States adopted a clearly paternalistic stance, in that as world hegemon it accepted the burden of 'civilising' these nations, there are also clear references made to post-intervention, self-reliance and self-governance. Therefore, the overall tone is hegemonic but not necessarily imperialistic.

"The American flag flies again over our Embassy in Kabul. Terrorists who once occupied Afghanistan now occupy cells at Guantanamo Bay. And terrorist leaders who urged followers to sacrifice their lives are running for their own. America and Afghanistan are now allies against terror. We'll be partners in rebuilding that country" (idem).

VI.4. Theme IV: U.S. responsibility towards oppressed and brutalised people struggling to survive under illiberal regimes and ideologies

The key words that are used here include 'freedom' and 'liberty' as brought to people suffering under the yoke of oppression and under authoritarian regimes. The stress in this theme is upon civil liberties and issues such as women's rights. It is interesting to note how, for instance, the Taliban's denial of women's right to education, political representation etc. is used to depict such groups as uncivilised, barbaric, backwards and illiberal and therefore necessitating intervention and removal. Thus, the successful securitisation of the terrorist threat along with the challenges it posed to the freedom and liberty of individuals, who lived in regions governed/controlled by these organisations, facilitated the recourse to military intervention that was founded on a clearly liberal logic of protecting the weak and helpless while simultaneously protecting the 'pacific federation'.

"The last time we met in this Chamber, the mothers and daughters of Afghanistan were captives in their own homes, forbidden from working or going to school. Today women are free and are part of Afghanistan's new Government. Our progress is a tribute to the spirit of the Afghan people, to the resolve of our coalition, and to the might of the United States military" (idem).

The sense that the United States would use military might for the benefit of the common man and for the democratic cause is repeated again and again in the discourse. In direct contrast to the empirical realities of 'collateral damage' in the GWoT, the discourse always emphasises the fact that aim of US military action is to target the oppressive regimes of Afghanistan and Iraq and not its 'starving', 'suffering', 'tyrannised' people:

"At the same time [as the US military conducts strikes against Al Qaeda and the Taliban regime], the oppressed people of Afghanistan will know the generosity of America and our allies. As we strike military targets, we will also drop food, medicine and supplies to the starving and suffering men and women and children of Afghanistan" (Bush 2001b).

"Many Iraqis can hear me tonight in a translated radio broadcast, and I have a message for them. If we must begin a military campaign, it will be directed against the lawless men who rule your country and not against you. As our coalition takes away their power, we will deliver the food and medicine you need. We will tear down the apparatus of terror and we will help you to build a new Iraq that is prosperous and free. In a free Iraq, there will be no more wars of aggression against your neighbors, no more poison factories, no more executions of dis- 
sidents, no more torture chambers and rape rooms. The tyrant will soon be gone. The day of your liberation is near" (Bush 2003b).

What comes across quite clearly in this discourse is the United State's sense of virtuousness. This logic essentially builds upon the ideas mentioned previously, i.e. first, that liberal values and democracy are universal and can thus find expression in US foreign policy and second, that the United States' efforts to secure its national interests also benefits the oppressed populations of the world. As Deputy Secretary of Defence Paul Wolfowitz stated, "Democracy is a universal idea and [...] letting people rule themselves happens to be something that serves Americans and America's interests as well" (Paul Wolfowitz as quoted in Desch 2007, p. 22). Also clearly evident in this discourse is the fact that the promotion of democracy was seen as significantly more important for US policy than stability. For instance, Secretary of Defence Donald Rumsfeld dismissed the looting and disorder in Iraq after the 2003 US invasion by declaring, "Freedom is untidy, and free people are free to make mistakes and commit crimes and do bad things. They are also free to live their lives and do wonderful things" (Donald Rumsfeld as quoted in Desch 2007, p. 24). Desch rightly points out that had the neoconservatives been interested in no more than a pro-US regime in Baghdad they would have been content to replace Saddam Hussein with a more amenable dictator rather than pushing for a democratically elected government, especially given both the commitment and turmoil that the later entailed. In fact, Wolfowitz even stated before the Iraq war commenced that the United States was "not interested in replacing one dictator with another" (Paul Wolfowitz as quoted in Desch 2007, p. 24). Thus instability was seen as part and parcel of the long march towards freedom and democracy.

\section{Conclusions}

This paper analysed the neoconservative practices and discourse of the Global War on Terror (GWoT) as seen in the statements made by George W. Bush and other key members of his administrations. I began by illustrating how the political roots of what can be best terms as the United States' recent turn to illiberal policy can in fact be traced to the philosophical thoughts of Immanuel Kant and John Stuart Mill. Indeed, the language and the logic behind the 'othering' and eventual securitisation of Al Qaeda/transnational terrorism and its allies are clearly rooted in both the language and ideas of Kant and Mill. I also highlighted that the tendency to adopt illiberal means to achieve ostensibly liberal ends is not a uniquely neoconservative trait. Instead it can be clearly located in American foreign policy since at least the beginning of the $20^{\text {th }}$ century. Thus, by framing Salafi-Jihadism as an exceptional act and as such a key existential threat to not only the United States' national security but also to the 'civilised world' and international and human security in general, the United States was able to frame its response as necessary war waged in defence of liberal freedoms and values. It was upon this logic that the interventions and projects of democracy promotion in Afghanistan and Iraq were predicated. These elements of the discourse and practice of the GWoT were demonstrated through a thematic analysis of key statements made by President Bush and other key personnel in his administration.

Of course, there were certain assumptions underpinning this stance, including the notion that liberalism and democracy are universal values as well as the belief that the United States was, as the world's sole superpower, best placed to defend these values. This in turn was predicated upon the deeply held political belief that in securing its national interests the United States would, as before, also be enhancing international security. There is no doubt that implicit in democracy promotion was a strategic (some would argue even imperialistic) im- 
perative, however there was also a historically rooted, normative sense of rightness and superiority evident in the discourse. In other words, it was upon both the material and the normative that America's sense of self-identity was predicated. What this meant was that that this particular self-perception deeply impacted how the United States' measured its success or failure against the threat posed by the Al Qaeda 'other'. Hence, the various aims under the GWoT - from controlling WMDs and protecting the American homeland to neutralising so-called rogue regimes and restricting the geographical reach of $\mathrm{Al}$ Qaeda to defeating it in the battle of arms and ideas - all depended upon the successful projection of US power, in the service of democracy promotion, in the international system. This is because it was through the establishment of democratic institutions and the protection of liberal freedoms and values that all these aims could be achieved. That the United States was willing to use armed intervention to achieve this end not only reflected its attempts to secure its position of unmatched advantage as the world's sole superpower but also its unique understanding of its exceptional position, rights and responsibilities in the post-Cold War world order.

The fact the United States was willing to use what were essentially illiberal means to achieve what were liberal ends reflects the deep paradox inherent in liberalism. Indeed one could argue that it is at the very intersection of strategic imperatives and self-perception that the shift to illiberalism occurred under the GWoT. Thus, it was the successful securitisation of Al Qaeda and rogue regimes immediately after the $9 / 11$ attacks that first pushed the United States towards defending its way of life and the liberal values and freedoms of the international system. In other words, it was in the process of attempting to guarantee both its own national security while simultaneously also fulfilling its role as hegemon, that it moved inexorably towards the adoption of illiberal policies. Internally these policies and practices were epitomised in the implementation and re-ratification of the PATRIOT act and progressively more significant restrictions on civil liberties in the name of national security. Externally, these illiberal practices were best seen in the flouting of established international norms governing the laws of war and the progressive erosion of human rights via policies of extraordinary rendition, incarceration and torture. Thus, one can argue that, the excesses of Abu Ghraib and Guantanamo were made possible because of the paradox inherent in liberalism - where illiberal means became acceptable in order to achieve liberal ends. The United States, as the perpetrator of these crimes was a liberal actor, indeed it was the 'beacon of freedom' and 'the defender of liberal values and opportunity'. But it was the deeply rooted liberal tradition within in the United States that pushed it towards viewing the threat from Al Qaeda in an alarmist, existential light and thus towards adopting what was an illiberal, unrestrained policy response. Thus, in viewing itself as 'exceptional' the United States not only moved towards a pre-emptive unilateralism but also in the course of the GWoT well beyond the pale of established international laws and regulations. In short, the unfortunate developments over the past fourteen years have essentially brought to light what authors like Louis Hartz argued had always rested at the very heart of US liberalism: its "intolerance verging on hysteria - in the face of non-liberal ideas and institutions" (Hartz 1955).

Rashmi Singh (rs71@st-andrews.ac.uk) é Doutora em Relações Internacionais pela London School of Economics and Political Science (Reino Unido) e Lecturer in Terrorism Studies at the Handa Centre for the Study of Terrorism and Political Violence (CSTPV), University of Saint Andrews (Escócia). 


\section{References}

Behnke, A. 2008. Eternal Peace as the Graveyard of the Political: A Critique of Kant's Zum Ewigen Frieden. Millennium, 36(3), pp. 513-531.

Berman, P. 2003. Terror and Liberalism. New York: W.W. Norton.

Boot, M. 2003. The Savage Wars of Peace: Small Wars and the Rise of American Power. New York: Basic Books.

Brown, C. 1992. International Theory: New Normative Approaches. Brighton: Harvester.

Buzan, B. 2004a. American Exceptionalism, Unipolarity and September 11: Understanding the Behaviour of the Sole Superpower. Paper presented at the International Studies Association. Montreal. .2004b. The United States and the Great Powers: World Politics in the Twenty-First Century. Cambridge (UK): Polity Press.

Caverley, J.D. 2010. Power and Democratic Weakness: Neoconservatism and Neoclassical Realism. Millennium, 38(3), pp. 593-614.

Derian, J.D. 2002. In Terrorem: Before and After 9/11. In K.B.T. Dunne, ed. Worlds in Collision: Terror and the Future of Global Order. Basingstoke: Palgrave Macmillian.

Desch, M.C. 2001. Liberals, Neocons and Realcons. Orbis, 45(4), pp. 519-533. .2007. America's Liberal Illiberalism: The Ideological Origins of Overreaction in U.S. Foreign Policy. International Security, 32(3), pp. 7-43.

Doyle, M.W. 1983a. Kant, Liberal Legacies and Foreign Affairs. Philosophy and Public Affairs, 12(3), pp. 205-235. . 1983b. Kant, Liberal Legacies, and Foreign Affairs, Part 2. Philosophy and Public Affairs, 12(4), pp. 323-353. 1986. Liberalism and World Politics. American Political Science Review, 80(4), pp. 1 151-1 169.

1996. Kant, Liberal Legacies and Foreign Affairs. In M.E. Brown; S.M. Lynn-Jones; S.E. Miller, eds. Debating the Democratic Peace Cambridge (MA): MIT Press.

1997. Ways of War and Peace. New York: W.W. Norton \& Co.

Dunne, T. 2009. Liberalism, International Terrorism and Democratic Wars. International Relations, 23(1), pp. 107-114.

Ehrenberg, J.; McSherry, J. P.; Sanchez, J. R.; Sayej, C.M., eds. 2010. The Iraq Papers. Oxford: Oxford University Press.

Freedman, L. 2005. The Age of Liberal Wars. Review of International Studies, 31(1), pp. 93-107.

2006a. Iraq, Liberal Wars and Illiberal Containment. Survival, 48(4), pp. 51-65. , ed. 2006b. The Transformation of Strategic Affairs. V. 379. London: Routledge.

Gallie, W.B. 1978. Philosophers of Peace and War Cambridge (UK): Cambridge University Press.

George, A.L. 2000. Foreword. In A.M. Kacowicz; Y. Bar-Siman-Tov; O. Elgström; M. Jerneck, eds. Stable Peace Among Nations. London: Rowman and Littlefield.

Grey, J. 2004. Two Faces of Liberalism. Cambridge (UK): Polity Press.

Hartz, L. 1955. The Liberal Tradition in America. San Diego: Harcourt.

Huntley, W.L. 1996. Kant's Third Image: Systemic Sources of the Liberal Peace. International Studies Quarterly, 40(1), pp. 45-76.

Jahn, B. 2005a. Barbarian Thoughts: Imperialism in the philosophy of John Stuart Mills. Review of International Studies, 31(3), pp. 599-618.

. 2005b. Kant, Mill and Illiberal Legacies in International Affairs. International Organization, 59(1), pp. 177-207.

Kagan, R. 2002. Power and Weakness. Policy Review, 113, pp. 1-29. 2003. Paradise and Power: America and Europe in the New World Order. London: Atlantic Books.

Kant, I. 1983. Perpetual Peace and Other Essays on Politics, History and Morals. Indianapolis: Hackett.

Krauthammer, C. 1990. The Unipolar Moment. Foreign Affairs, 70(1), pp. 23-33.

Kurth, J. 2004. Iraq: Losing the American Way. The American Conservative, 15 Mar. Disponível em: http://www.theamericanconservative.com/articles/iraq-losing-the-american-way/. Acesso em: 4 fev 2015.

2005. Ignoring History: U.S. Democratization in the Muslim World. Orbis, 49(2), pp. 305-322.

Linn, B.M. 1989. The U.S. Army and Counterinsurgency in the Philippine War, 1899-1902. Chapel Hill: University of North Carolina.

MacMillan, J. 1996. Democracies Don't Fight: A case of the wrong research agenda? Review of International Studies, 22(3), pp. 275-299.

Mead, W.R. 2002. Special Providence: American Foreign Policy and How it Changed the World. London: Routledge.

Mehta, U.S. 1999. Liberalism and Empire: A Study in Nineteenth-Century British Liberal Thought. Chicago: University of Chicago Press.

Mill, J.S. 1984. A Few Words on Non-intervention. In J.M. Robson, ed. The Collected Works of John Stuart Mill. V. 21: Essays on Equality, Law and Education. Toronto: Toronto University Press.

1990. Essays on Politics and Culture. Massachusetts: Peter Smith Pub. Inc. 2005. On Liberty. New York: Cosimo Inc.

Miller, B. 2010. Democracy Promotion: Offensive Liberalism vs. the rest (of IR Theory). Millennium, 38(3), pp. 561-591. 
Monten, J. 2005. The Roots of the Bush Doctrine: Power, Nationalism and Democracy Promotion in U.S. Strategy. International Security, 29(4), pp. 112-156.

Müller, H. 2014. Evilization in Liberal Discourse: From Kant's 'unjust enemy' to today's 'rogue state'. International Politics, 15(4), pp. 475-491.

Passavant, P.A. 2002. No Escape: Freedom of speech and the paradox of rights. New York: New York University Press.

Pitts, J. 2005. A Turn to Empire: The Rise of Imperial Liberalism in Britain and France. New Jersey: Princeton University Press Reus-Smit, C. 2004. American Power and World Order. Cambridge (UK): Polity Press.

Rice, C. 2000. Promoting the National Interest. Foreign Affairs, 75(1), pp. 45-62.

Singh, R. 2012. Measuring “Al-Qaeda”: The Metrics of Terror. In A.B.C. Hellmich, ed. Knowing Al-Qaeda: The Epistemology of Terrorism. London: Ashgate.

Smith, T. 1993. America's Mission: The United States and the Worldwide Struggle for Democracy in the Twentieth Century. Princeton: Princeton University Press.

Souffrant, E.M. 2000. Formal Transgressions: John Stuart Mill's Philosophy of International Affairs. Lanham: Rowman and Littlefield.

Steel, R. 2003. The Missionary. The New York Review of Books, 50(18).

Thompson, W.R. 1996. Democracy and Peace: Putting the cart before the horse? International Organization, 50(1), pp. 141-174.

Waltz, K.N. 1954. Man, the State and War: A Theoretical Analysis. New York: Columbia University Press.

Williams, A. 2006. Liberalism and War: The victors and vanquished. London: Routledge.

Other sources

Bush, G.W. 2001a. 9/11 Address to the Nation: A Great People Has Been Moved to Defend a Great Nation. Washington, D.C.:

The White House. Retrieved from http://www.americanrhetoric.com/speeches/gwbush911addresstothenation.htm. Accessed 4 Feb 2015.

. 2001b. President Bush Announces Strikes Against Taliban. The Washington Post, 7 Oct. Retrieved from http://www.washingtonpost.com/wp-srv/nation/specials/attacked/transcripts/bushaddress_100801.htm. Acessed 4 Feb 2015.

.2002. Address Before a Joint Session of the Congress on the State of the Union. Washington, D.C.: The White House. Retrieved from http://www.presidency.ucsb.edu/ws/index.php?pid = 29644. Accessed 4 Feb 2015. . 2003a. Address Before a Joint Session of the Congress on the State of the Union. Washington, D.C.: The White House. Retrieved from http://www.presidency.ucsb.edu/ws/index.php?pid = 29645. Acessed 4 Feb 2015.

2003b. Message to Saddam. Washington, D.C.: The White House. Retrieved from http://www.presidentialrhetoric.com/speeches/03.17.03.html. Acessed 4 Feb 2015.

.2005a. Address Before a Joint Session of the Congress on the State of the Union. Washington, D.C.: The White House. Retrieved from http://www.presidency.ucsb.edu/ws/index.php?pid = 58746. Accessed 4 Feb 2015.

. 2005b. President Sworn-In to Second Term: Inaugural Address. Washington, D.C.: The White House. Retrieved from http://georgewbush-whitehouse.archives.gov/news/releases/2005/01/20050120-1.html. Accessed 4 Feb 2015. . 2006. Address Before a Joint Session of the Congress on the State of the Union. Washington, D.C.: The White House. Retrieved from http://www.presidency.ucsb.edu/ws/index.php?pid = 65090. Acessed 4 Feb 2015.

Cheney, D. 2002. Remarks by the Vice President to the Council on Foreign Relations. Washington, D.C.: The White House. Retrieved from http://georgewbush-whitehouse.archives.gov/vicepresident/news-speeches/. Acessed 4 Feb 2015.

Kaplan, L.F. 2003. Regime Change: Bush, Closet Liberal. New Republic, 3 Mar. Retrieved from http://www.newrepublic.com/article/bush-middle-east-conservative-woodrow-wilson-liberalism. Accessed 4 Feb 2015.

Kennedy, D.M. 2005. What 'W' Owes to 'WW'. The Atlantic Monthly, 295(2), 1 Mar. Retrieved from http://www.theatlantic.com/magazine/archive/2005/03/what-w-owes-to-ww/303731/. Accessed 4 Feb 2015.

Rice, C. 2004. National Security Advisor Discusses War on Terror at McConnell Center for Political Leadership. Washington, D.C.: The White House. Retrieved from http://repositories.lib.utexas.edu/bitstream/handle/2152/13109/Rice_WaronTerror_UL.pdf. Accessed 4 Feb 2015.

United States. 2002. The National Security Strategy of the United States of America. Washington, D.C.: The White House. 


\section{Resumo}

Este trabalho apresenta uma análise das práticas e discursos iliberais da Guerra Global Contra o Terror (GWoT, na sigla em inglês) e demonstra como os Estados Unidos da América usaram o argumento liberal como uma métrica qualitativa do seu sucesso e fracasso na GWoT. Argumento que o "estranhamento do outro" (salafistas jihadistas) - bem como o envolvimento militar no Afeganistão e Iraque foram filosoficamente enraizadas no pensamento liberal de Immanuel Kant e John Stuart Mill, que tradicionalmente têm guiado a política externa estadunidense. Mais significativamente, essas filosofias liberais da história e das relações internacionais têm dentro de si as sementes do iliberalismo ao descrever sociedades/organizações não-liberais e antidemocráticas como "bárbaras" - e, como tal, os principais candidatos para a intervenção e mudança de regime. Predicado nessa lógica, o discurso da GWoT enquadrou a Al Qaeda como uma ameaça existencial chave, não apenas para os Estados Unidos, mas também para o "mundo civilizado" em geral, exigindo então uma "guerra defensiva liberal" em resposta. Foi o sucesso da securitização da Al Qaeda que essencialmente permitiu aos Estados Unidos adotarem políticas profundamente iliberais para combater esta dita ameaça existencial utilizando-se de todos os meios à sua disposição

PALAVRAS-CHAVE: Liberalismo; Guerra Global ao Terror; Estados Unidos; Immanuel Kant; John Stuart Mill.

License information: This is an open-access article distributed under the terms of the Creative Commons Attribution License, which permits unrestricted use, distribution, and reproduction in any medium, provided the original work is properly cited. 